\title{
Study of Cytodiagnosis of Head and Neck Neoplastic Lesions and Comparison with Histopathology
}

\author{
Maniyar U Amit, Harshid Laxmanbhai Patel, BH Parmar
}

\begin{abstract}
Introduction: The development of aspiration cytology is one of the biggest advances in anatomic pathology. Cancer has become one of the 10 leading causes of death in India. Head and neck neoplasia is a major form of cancer in India, accounting for $23 \%$ of all cancers in males and $6 \%$ in females. The advantages of fine needle aspiration cytology (FNAC) are: it is safe, sensitive and specific for the diagnosis of malignancy, gives a rapid report, requires little equipment, causes minimal discomfort to the patient, is an out patient procedure, repeatable and cost effective avoids the use of frozen section, reduces the rate of exploratory procedures and allows a definitive diagnosis of inoperable cases. FNAC is of particular relevance in head and neck lesions because of easy assessibility, excellent patient compliance, minimally invasive nature of procedure and helping to avoid surgery in non-neoplastic lesions, inflammatory conditions and also some tumors.
\end{abstract}

Aims and objectives: To test the utility of FNAC, to establish the diagnostic accuracy of cytology by comparison with histopathology diagnosis and to establish the sensitivity and specificity of this technique in head and neck neoplastic lesion.

Materials and methods: The present study was undertaken in the Department of Pathology, Government Medical College and Hospital, Nashik, between January 2008 and June 2009.

Results: In the present study, maximum number of aspirates from head and neck neoplastic lesions were found to be of lymph nodes (56.37\%). Of the total 378 cases, $71.69 \%$ were malignant. 6th decade was the most common age group affected $(26.46 \%)$. Mean age group was found to be 45.84 years. Males were more commonly affected $(65.34 \%)$. The male to female ratio was 1.8:1. Out of 92 cases available for follow-up, $85.87 \%$ of the cases were same as histopathological diagnosis.

Summary and conclusion: Excisional biopsy remains the gold standard for diagnosis of head and neck neoplastic lesion, cytological study can establish the diagnosis of the majority of head and neck neoplastic lesions and can be recommended as an adjunct to histopathology.

Keywords: Fine niddle aspiration cytology, Head and neck neoplastic lesions, Histopathological confirmation.

How to cite this article: Amit MU, Patel HL, Parmar BH. Study of Cytodiagnosis of Head and Neck Neoplastic Lesions and Comparison with Histopathology. Int J Head Neck Surg 2013; $4(3): 119-122$.

\section{Source of support: Nil}

Conflict of interest: None declared

\section{INTRODUCTION}

Lesions of head and neck are comprised of developmental, inflammatory and neoplastic conditions. Most commonly seen swellings are branchial cysts, thyroglossal cysts, dermoid cysts, lymphangioma, hemangioma, lymphadenitis, sialadenitis and neoplastic pathologies. ${ }^{1}$ Fine needle aspiration cytology (FNAC) is of particular relevance in the head and neck area because of easy accessibility of the target site, excellent patient compliance, minimally invasive nature of the procedure and helping to avoid surgery in nonneoplastic lesions, inflammatory conditions and also some tumors. ${ }^{2}$ Martin introduced this technique in the evaluation of head and neck lesions in 1930 and the procedure has since then become increasingly popular and is being frequently used in the evaluation of swellings of this region. ${ }^{3,4}$ The FNAC has a accuracy rate exceeding $92 \% .^{5,6}$

The idea to obtain cells and tissue fragments through a needle introduced into the abnormal tissue was by no means new. The development of aspiration cytology is one of the biggest advances in anatomic pathology in the forthcoming decade would be the development and application of aspiration cytology. ${ }^{7}$

Cancer has become one of the 10 leading causes of death in India. ${ }^{8}$ Head and neck neoplasia is a major form of cancer in India, accounting for $23 \%$ of all cancers in males and $6 \%$ in females. ${ }^{9} 10$ India has also the dubious distinction of having the world's highest reported incidence of head and neck neoplasia in women. ${ }^{10}$

FNAC is of particular relevance in the head and neck area because of easy accessibility of target sites, excellent patient compliance, minimally invasive nature of the technique and the important aspect of avoidance of surgery in situations like non-neoplastic or inflammatory conditions and metastatic tumors. ${ }^{2}$

The advantages of FNAC are: It is safe, sensitive and specific for the diagnosis of malignancy, an outpatient procedure, repeatable and cost-effective, ${ }^{11}$ gives a rapid report, requires little equipment, causes minimal discomfort to the patient, reduces bed occupancy, allows preoperative diagnosis, avoids the use of frozen section, reduces the rate of exploratory procedures and allows a definitive diagnosis of inoperable cases.

Correlation of cytological diagnosis with histopathological findings in the surgical specimen aids in developing a level of comfort with the pathologist's cytological interpretation. ${ }^{12}$ Stewart's opinion of the technique is still valid today as it was in 1933 when he stated 'diagnosis by aspiration is as reliable as the combined intelligence of the clinicians and pathologists makes it'. ${ }^{13}$ 


\section{AIMS AND OBJECTIVES}

1. To test the utility of FNAC in diagnosis of head and neck neoplastic lesions.

2. To establish the diagnostic accuracy of cytology by comparative study with histopathological diagnosis.

3. To establish the sensitivity and specificity of this technique in head and neck neoplastic lesion.

\section{MATERIALS AND METHODS}

The present study was undertaken in the Department of Pathology, Government Medical College and Hospital, Nashik, between January 2008 and June 2009. Few patients were also taken from leading histopathology laboratory in the city.

Approval from the Institutional Ethical Committee and fromEthical Committee of Maharashtra University of Health Sciences (MUHS), Nashik, was takenbefore commencing study.

The patients presented with superficially palpable head and neck lesion, patient admitted in hospital ward of this institute with clinical diagnosis of any head and neck neoplastic lesions and patients attending cytological OPD in a private laboratory with head and neck lesion were selected for this study.

FNAC was done in cytology section of central clinical laboratory or in respective ward in which the patient was admitted. The method of FNAC used in the present study is same as described by Franzen et al. Aspiration was carried out using $20 \mathrm{ml}$ disposable syringe with 23 to 25 gauze needle attached to Franzen's aspiration handle. Two or three wet smears were prepared following the guidelines laid down in the manual and atlas of FNAC, [Svante R Orell, Gregory F Sterrett, Darrel Whitaker (4thed), 2005]. ${ }^{14}$ Then fixed in $95 \%$ ethyl alcohol and others were air dried and routinely stained with papanicolaou (PAP)/hematoxylinandeosin(H\&E) stains.

Findings of FNAC were recorded and patients were advised nonoperative treatment and follow-up or biopsy and surgical intervention depending upon the pathology.

The received postoperative surgical specimen was fixed in $10 \%$ neutral formalin and subjected to gross examination, processing, paraffin embedding, section cutting, staining by H\&E and mounting by DPX. The cytomorphological features of various diseases were studied. FNAC and histopathological examination (HPE) of the same lesion were correlated where available.

\section{RESULTS}

In the present study, total of 385 aspirates from 378 cases were studied for cytohistological correlation in the head and neck neoplastic lesions.

\section{DISCUSSION}

The present study was carried out at Department of Pathology, Government Medical College and Hospital, from January 2008 to June 2009. Total of 385 aspirates from 378 cases of head and neck neoplastic lesions were studied to test the efficacy and overall utility of cytology in the head and neck neoplastic lesions.

Table 1 shows the site-wise distribution of various head and neck neoplastic lesions. Maximum number of aspirates were from lymph nodes (56.37\%) followed by soft tissue lesions $14.80 \%$ whereas salivary gland lesions accounted for $11.44 \%$ and thyroid lesions accounted for $10.90 \%$ and miscellaneous lesions accounting for $06.49 \%$ cases. Cheng and Dorman $(1992)^{15}$ aspirated 110 head and neck neoplastic lesions from which $46(41.82 \%)$ were from lymph node, $7(06.36 \%)$ were from thyroid and $14(12.73 \%)$ were from salivary gland. Mui et al $(1997)^{16}$ aspirated 35 head and neck neoplastic lesions from which 15 (42.86\%) were from lymph node, $4(11.43 \%)$ were from thyroid and $11(31.43 \%)$ were from salivary gland. El Hag et al (2003) ${ }^{17}$ aspirated 49 head and neck neoplastic lesions from which 28 (57.14\%) were from lymph node and $9(18.37 \%)$ were from salivary gland.

Table 2 shows that in present study total number of benign cases were found to be $107(28.31 \%)$ whereas the malignant cases were $271(71.69 \%)$ cases. Andleeb Abrari et al (2002) ${ }^{2}$ aspirated 115 neoplastic cases of head and neck lesions of which $55(47.83 \%)$ were benign and $60(57.12 \%)$ were malignant. El Hag et al $(2008){ }^{17}$ aspirated 49 neoplastic cases of head and neck lesions of which $20(40.82 \%)$ were benign and $29(59.18 \%)$ were malignant. Mui et al $(2008)^{16}$ aspirated 35 neoplastic cases of head and neck lesions of which $14(40 \%)$ were benign and $21(60 \%)$ were malignant.

Table 3 shows that, in present study, the 51 to 60 years age group $(26.46 \%)$ is the most common affected by head and neck neoplastic lesions followed by the $>60$ years age group and 41 to 51 years age group. The mean age group was found to be 45.84 years. In study of El Hag et al ${ }^{17}$ the mean age group was found to be 33.0 years; in study of Shykhon et al, ${ }^{18}$ the mean age group was found to be 52.0 years while in study of Jandu and Webster et al ${ }^{19}$ the mean age group was found to be 51.0 years.

Table 4 shows that, in present study, out of the total 378 cases, $247(65.35 \%)$ were males and $131(34.65 \%)$ females. So, the male to female ratio was $1.8: 1$. In study of Cheng and

Table 1: Site-wise distribution of various head and neck neoplastic lesions

\begin{tabular}{clcc}
\hline Sr. no. & Lesions & No. of aspirates & $\%$ \\
\hline 1 & Lymph node & 217 & 56.37 \\
2 & Salivary gland & 044 & 11.44 \\
3 & Thyroid & 042 & 10.90 \\
4 & Soft tissue & 057 & 14.80 \\
5 & Skin and subcutaneous & 017 & 04.42 \\
6 & Nasal/PNS & 006 & 01.55 \\
7 & Odontogenic/bony & 002 & 00.52 \\
\hline & Total & 385 & 100.0 \\
\hline
\end{tabular}

Maximum number of aspirates from head and neck neoplastic lesions were found to be of lymph nodes $(56.37 \%)$ 
Dorman, ${ }^{15}$ it was 1.5:1, in study of Jandu and Webster et al, ${ }^{19}$ it was 1.3:1 and, in study of El Hag et al, ${ }^{17}$ it was 1.1:1. Male to female ratio is slightly higher in the present study compared to other studies.

Table 5 shows cytohistological correlation of various head and neck neoplastic lesions. In the present study, out of the total 385 aspirates, $92(23.90 \%)$ cases were available for follow-up and histopathology. Out of these 92 cases, in $79(85.87 \%)$ cases, cytological diagnosis was same as histopathological diagnosis. Whereas in $13(14.13 \%)$ cases, the cytologic diagnosis and final histopathological diagnosis were different.

\section{SUMMARY}

This prospective study of cytodiagnosis of head and neck neoplastic lesions and mapping patterns of head and neck cancers was carried out at Government Medical College and Hospital from January 2008 to June 2009.

A total number of 385 aspirates were obtained of head and neck neoplastic lesions. The majority of aspirates were from lymph nodes $(56.37 \%)$ followed by soft tissue lesions $(14.80 \%)$ whereas salivary gland lesions accounted for $11.44 \%$ and thyroid lesions accounted for $10.90 \%$ and miscellaneous lesions $6.49 \%$ cases.

A total of $71.69 \%$ cases of head and neck neoplastic lesions were reported as malignant on cytology.

The most common age group was 6th decade $(26.46 \%)$ and mean age group of patients with head and neck neoplastic lesion was 45.84 years.

Male to female ratio for head and neck neoplastic lesion was 1.8:1.

Out of the total 385 cases, 92 cases $(23.90 \%)$ were available for follow-up and histopathology. One false negative case was found but no false positive cases were found. The diagnostic accuracy of the present study of head and neck neoplastic lesion to be $98.91 \%$. The sensitivity was found to be $98.46 \%$ and the specificity was $100 \%$.

We recommend that FNAC to be a safe and reliable technique in diagnosis of head and neck lesions. It is a quick, convenient and accurate method of tissue diagnosis and should be considered as first line investigation in the evaluation of lesions in head and neck region.

This cytological study of head and neck neoplastic lesions showed that, FNAC is a simple, rapid, safe, atraumatic

Table 3: Age-wise distribution of head and neck neoplastic lesions

\begin{tabular}{cccc}
\hline Sr. no. & Age group & No. of cases & $\%$ \\
\hline 1 & $0-10$ & 015 & 03.96 \\
2 & $11-20$ & 019 & 05.04 \\
3 & $21-30$ & 044 & 11.64 \\
4 & $31-40$ & 049 & 12.96 \\
5 & $41-50$ & 058 & 15.34 \\
6 & $51-60$ & 100 & 26.46 \\
7 & $>60$ & 093 & 24.60 \\
\hline Total & & 378 & 100.0 \\
\hline
\end{tabular}

6 th decade was the most common age group affected (26.46\%) followed by $>60$ years age group. Mean age group for head and neck neoplastic lesions was found to be 45.84 years

Table 4: Site-wise sex distribution of head and neck neoplastic lesions

\begin{tabular}{clccc}
\hline Sr. no. & Lesions & Male & Female & Total \\
\hline 1 & Lymph node & 169 & 48 & 217 \\
2 & Soft tissue & 36 & 21 & 57 \\
3 & Salivary gland & 24 & 20 & 44 \\
4 & Thyroid & 08 & 34 & 42 \\
5 & Skin and subcut. & 09 & 08 & 17 \\
6 & Nasal/PNS & 03 & 03 & 06 \\
7 & Odontogenic/bony & 02 & 00 & 02 \\
\hline Overall & & 247 & 131 & 378 \\
& & 65.34 & 34.66 & 100.0 \\
\hline
\end{tabular}

Males were more commonly affected (65.34\%). The male to female ratio was 1.8:1

Table 2: Cytodiagnosis of cases with head and neck neoplastic lesions

\begin{tabular}{|c|c|c|c|c|c|}
\hline Sr. no. & Lesions & Total & & Aspirates & $\%$ \\
\hline 1 & Lymph node & 217 & $\begin{array}{l}\text { Benign } \\
\text { Malignant }\end{array}$ & $\begin{array}{r}00 \\
217\end{array}$ & $\overline{100.0}$ \\
\hline 2 & Salivary gland & 44 & $\begin{array}{l}\text { Benign } \\
\text { Malignant }\end{array}$ & $\begin{array}{l}36 \\
08\end{array}$ & $\begin{array}{l}81.81 \\
18.18\end{array}$ \\
\hline 3 & Thyroid & 42 & $\begin{array}{l}\text { Follicular neoplasm } \\
\text { Malignant }\end{array}$ & $\begin{array}{l}31 \\
11\end{array}$ & $\begin{array}{l}73.81 \\
26.19\end{array}$ \\
\hline 4 & Soft tissue & 57 & $\begin{array}{l}\text { Benign } \\
\text { Malignant }\end{array}$ & $\begin{array}{l}56 \\
01\end{array}$ & $\begin{array}{l}98.25 \\
01.75\end{array}$ \\
\hline 5 & Skin and subcutaneous & 17 & $\begin{array}{l}\text { Benign } \\
\text { Malignant }\end{array}$ & $\begin{array}{l}10 \\
07\end{array}$ & $\begin{array}{l}58.82 \\
41.18\end{array}$ \\
\hline 6 & Nasal/PNS & 06 & $\begin{array}{l}\text { Benign } \\
\text { Malignant }\end{array}$ & $\begin{array}{l}03 \\
03\end{array}$ & $\begin{array}{l}50.00 \\
50.00\end{array}$ \\
\hline 7 & Odontogenic/bony & 02 & $\begin{array}{l}\text { Benign } \\
\text { Malignant }\end{array}$ & $\begin{array}{l}02 \\
00\end{array}$ & $\begin{array}{c}100.0 \\
-\end{array}$ \\
\hline & Total cases & 378 & $\begin{array}{l}\text { Benign } \\
\text { Malignant }\end{array}$ & $\begin{array}{l}107 \\
271\end{array}$ & $\begin{array}{l}28.31 \\
71.69\end{array}$ \\
\hline
\end{tabular}

Of the total 378 cases with neoplastic head and neck lesions, $71.69 \%$ were malignant and $28.31 \%$ were benign 
Table 5: Cytohistopathological correlation of head and neck neoplastic lesions

\begin{tabular}{llcccc}
\hline Sr. no. & Lesions & Total cytology & Total histology & Consistent & Inconsistent \\
\hline 1 & Lymph node & 217 & 48 & 44 & 04 \\
2 & SG & 44 & 17 & 08 & 04 \\
3 & Thyroid & 42 & 10 & 08 & 02 \\
4 & Soft tissue & 57 & 09 & 05 & 01 \\
5 & Skin and SC & 17 & 05 & 01 & 01 \\
6 & Nasal/PNS & 06 & 02 & 00 & 01 \\
7 & Odonto/jaw & 02 & 01 & 79 & 13 \\
\hline & Total & 385 & 92 & 85.87 & 14.13 \\
\hline
\end{tabular}

Around 92 cases were available for follow-up and histopathological confirmation. Out of these, $79(85.87 \%)$ of the cases were same as histopathological diagnosis. Whereas in $13(14.13 \%)$ cases, the cytologic diagnosis and final histopathological diagnosis were different

procedure, free of complications, cost-effective, virtually painless and is well tolerated by the patient, including the pediatric population and on an outpatient basis.

\section{CONCLUSION}

While excisional biopsy remains the gold standard for diagnosis of head and neck neoplastic lesion, cytological study can establish the diagnosis of the majority of head and neck neoplastic lesions and can be recommended as an adjunct to histopathology.

\section{ACKNOWLEDGMENT}

The authors thank to all the patients, all staffs of Cytopathology and Histopathology Department of Government Medical College and Hospital, Nashik, Maharashtra.

\section{REFERENCES}

1. McGuirt WF. Differential diagnosis of neck masses. In: Cummings CW, Flint PW, Harkar LA (Eds). Cummings Otolaryngology Head and Neck Surgery (4th ed). Mosby: Elsevier 2005:2542.

2. Abrari A, Ahmad SS, Bakshi V. Cytology in the otorhinolaryngologists domain: A study of 150 cases, emphasizing diagnostic utility and pitfalls. Ind J Otolarnyngol Head Neck Surg 2002;54(2):107-10.

3. Martin H, Ellis EB. Biopsy of needle puncture and aspiration. Ann Surg 1930;92:169-81.

4. Platt JC, Davidson D, Nelson CL, Weiseberger E. Fine needle aspiration biopsy. An analysis of 89 head and neck cases. J Oral Maxillofac Surg 1990;48:702-06.

5. Johnson JT, Zimmer L. Fine needle aspiration of neck masses. Available from: http://emedicine.medscape.com/article/ 1819862-overview.

6. Watkinson JC, Gaze MN, Wilson JA. Stell and Maran's Head and Neck Surgery (4th ed). Oxford: Butterworth Heinemann 2000: p21.

7. Gray W, McKee GT. Diagnostic cytopathology (2nd ed). London: Churchill Livingstone; 2003:6.

8. Rao YN, Gupta S, Agarwal SP. National Cancer Control Programme: Current status and strategies. In: Agarwal SP (Ed). Fifty years of cancer control in India. Dir Gen of Health Services, MOHFW, Government of India 2002;41-47.

9. Ahluwalia H, Gupta SC, Singh M, Gupta SC, Mishra V, Singh PA, et al. Spectrum of head and neck cancers at Allahabad. J Otolaryngol Head Neck Surg 2001;53:16-20.
10. Mehrotra R, Singh M, Gupta RK, Singh M, Kapoor AK. Trends of prevalence and pathological spectrum of head and neck cancers in North India. Indian J Cancer 2005;42:89-93.

11. Geddie WR. Fine needle aspiration cytology: Diagnostic principles and dilemmas. J Clin Pathol 2007;60(3):335-36.

12. Amedee RG, Dhurandhar NR. Fine needle aspiration biopsy. Laryngoscope 2001;111(9):1551-57.

13. Silverberg SG, DeLellis RA, Frable WJ, LiVolsi VA, Wick MR (Eds). Silverberg's principles and practice of surgical pathology and cytopathology (4th ed). NY: Churchill Livingstone-Elsevier; 2006;22.

14. Firat P, Ersoz C, Uguz A, Onder S. Cystic lesions of the head and neck: Cytohistological correlation in 63 cases. Cytopathology 2007;18(3):184-90.

15. Cheng AT, Dorman B. Fine needle aspiration cytology: The Auckland experience. Aust N Z J Surg 1992 May;62(5):368-72.

16. Mui S, Li T, Rasgon BM, Hilsinger RL, Rumore G, Puligandla B, et al. Efficacy and cost-effectiveness of multihole fine-needle aspiration of head and neck masses. Laryngoscope 1997 Jun; 107(6):759-64.

17. El Hag IA, Chiedozi LC, al Reyees FA, Kollur SM. Fine needle aspiration cytology of head and neck masses. Seven years' experience in a secondary care hospital. Acta Cytol 2003;47(3): 387-92.

18. Shykhon M, Macnamara M, El-assy A, Warfield AT. Role of repeat fine needle aspiration cytology in head and neck lesions: Preliminary study. J Laryngol Otol 2004;118(4):294-98.

19. Jandu M, Webster $K$. The role of operator experience in fine needle aspiration cytology of head and neck masses. Int J Oral Maxillofac Surg 1999;28:441-44.

\section{ABOUT THE AUTHORS}

\section{Maniyar U Amit}

Assistant Professor, Department of Pathology, CU Shah Medical College, Surendranagar, Gujarat, India

\section{Harshid Laxmanbhai Patel}

Assistant Professor, Department of Pathology, GMERS Medical College, Dharpur, Patan, Gujarat, India

Correspondence Address: 229, Raj Bunglow, Near Raj Nagari Shanti Niketan School Road, Ambaji Nagar, Patan (NG), Gujarat384265, India, e-mail: drhlp1975@gmail.com

\section{BH Parmar}

Professor and Head, Department of Pathology, GMERS Medical College, Dharpur, Patan, Gujarat, India 